\section{Environmental Control of Flowering and Growth of Achillea millefolium L. 'Summer Pastels'}

\author{
D. Zhang, A.M. Armitage, J.M. Affolter, and M.A. Dirr \\ Department of Horticulture, University of Georgia, Athens, GA 30602-7273
}

Additional index words. yarrow, photoperiod, temperature, irradiance

\begin{abstract}
Achillea millefolium 'Summer Pastels' is a qualitative long-day plant with a critical photoperiod between 12 and 16 hours at 18C. Plants grown under a 16-hour photoperiod flowered after 27 days, while those under 8 hours remained vegetative. Shoot dry weight was not affected by photoperiod. Low temperature (10C) delayed the time of flower bud formation and anthesis by $\approx 20$ days. Low irradiance $\left(100 \mu \mathrm{mol} \cdot \mathrm{m}^{-2} \cdot \mathrm{s}^{-1}\right)$ delayed flowering and resulted in lower shoot dry weight, while moderate shading $(200$ $\left.\mu \mathrm{mol} \cdot \mathrm{m}^{-2} \cdot \mathrm{s}^{-1}\right)$ did not significantly affect flowering time and growth compared with high irradiance levels $\left(300 \mu \mathrm{mol} \cdot \mathrm{m}^{-2} \cdot \mathrm{s}^{-1}\right)$.
\end{abstract}

Achillea millefolium (Asteraceae) is native to Europe and Western Asia and widely naturalized in temperate regions. It grows vigorously and is often considered a troublesome weed (Armitage, 1987a); however, many ornamental cultivars have been introduced and selections of the species are now considered important garden plants. These selections also have significant potential for the cut flower market (Armitage, 1992). In recent field studies, Armitage (1992) reported that $A$. millefolium produced more flower stems than other cultivated Achillea and had the highest yield, regardless of spacing. There was no obvious change of flower size and stem diameter as the density of plants increased (Armitage, 1987b). Engle et al. (1993) found that a related species, A. filipendulina Lam. 'Cloth of Gold', produces terminal and lateral buds under short days but only terminal buds under long days. Iversen (1989) demonstrated that $A$. millefolium 'Rosea' is a long-day plant and that daylength and cold treatment have significant effects on flower formation and maturation.

Achillea millefolium 'Summer Pastels' is a new seed-produced cultivar suitable as a garden plant and specialty cut flower. Plants produce flowers from salmon to purple-gray in color and they can be used in the garden, container, and xeriscapic landscapes (Bailey et al., 1976). Plants reproduce by seeds and fragments of rhizomes. Seed is easily germinated under warm, humid conditions, while rhizomes can be divided any time, but preferably in early spring or immediately after flowering (Armitage, 1993). 'Summer Pastels' and other compact forms of $A$. millefolium also may be useful as pot plants; however, specific

Received for publication 18 Aug. 1995. Accepted for publication 13 Jan. 1996. Thanks to American Floral Endowment and Gloeckner Foundation for supporting this work. The cost of publishing this paper was defrayed in part by the payment of page charges. Under postal regulations, this paper therefore must be hereby marked advertisement solely to indicate this fact. environmental optima for flower production have not been determined. This research examined the influences of photoperiod, temperature, and irradiance on flowering and growth of A. millefolium 'Summer Pastels'.

\section{Materials and Methods}

One-year-old plants of A. millefolium 'Summer Pastels' in 510-ml $(10-\mathrm{cm})$ pots were divided into four equal groups, potted in trays $(3 \times 8$ cells, $277 \mathrm{ml} / \mathrm{cell})$, and grown under intermittent mist in a glasshouse. Well-rooted divisions were transplanted to standard 510$\mathrm{ml}$ plastic pots in LC1 Fison Sunshine Mix (Bellevue, Wash.) and moved to growth chambers (Conviron CMP3244, Asheville, N.C.). Plants were fertilized at irrigation as needed with $\mathrm{N}$ at $50 \mathrm{mg} \cdot \mathrm{liter}^{-1}$ for the first 2 weeks, then $100 \mathrm{mg} \cdot \mathrm{liter}^{-1}$ using $15 \mathrm{~N}-9.9 \mathrm{P}-14.1 \mathrm{~K}$ throughout the duration of the experiments. Top water was applied every fourth irrigation to avoid the accumulation of salt.

Three separate experiments were conducted. To evaluate the influence of photoperiod, seven plants were placed under 8-, 12-, or 16-h photoperiods on 10 Mar. 1993. Temperature for all treatments was $20 \pm 2 \mathrm{C}$. Light (photosynthetic photon flux) with incandescent and fluorescent bulbs (50:50 input wattage) was $200,133.3$, and $100 \mu \mathrm{mol} \cdot \mathrm{m}^{-2} \cdot \mathrm{s}^{-1}$ for 8-, 12-, and 16-h photoperiods, respectively, and the cumulative light was $5.8 \pm 0.4$ $\mathrm{mol} \cdot \mathrm{m}^{-2} \cdot \mathrm{d}^{-1}$ for all treatments. For the temperature experiment, seven plants were placed of treatment.

${ }^{\mathrm{z}} \mathrm{L}=$ linear, $\mathrm{Q}=$ quadratic trend

Ns, * Nonsignificant or significant at $P \leq 0.05$, respectively. in each of the three chambers at constant $10 \pm$ $2,18 \pm 2$, or $26 \pm 2 \mathrm{C}$ from 1 June 1993 . Evidence from the photoperiod experiment suggested that long days enhanced flowering; therefore, the photoperiod used was 16 $\mathrm{h} \cdot \mathrm{day}^{-1}$ and light intensity was $100 \pm 18$ $\mu \mathrm{mol} \cdot \mathrm{m}^{-2} \cdot \mathrm{s}^{-1}$. The temperature experiment was repeated 27 June 1994, with 6-week-old seedlings from Greenleaf Enterprises (Leola, Pa.). Plants were transplanted as mentioned above. For the irradiance experiment, seven plants were moved to each of the three chambers with irradiance of $100 \pm 15,200 \pm 20$, and $300 \pm 51$ $\mu \mathrm{mol} \cdot \mathrm{m}^{-2} \cdot \mathrm{s}^{-1}$ from 18 Aug. 1993 . The photoperiod was $16 \mathrm{~h} \cdot \mathrm{day}^{-1}$ and temperature was $20 \pm$ 2C.

A completely randomized design was used in all experiments. Plants were rotated in the chambers every 3 days to ensure complete randomization. Time to visible flower buds, defined as the time when the inflorescence diameter was $\approx 1 \mathrm{~cm}$, was recorded and plant height and shoot dry weight were measured at the end of the experiment. Data were tested using an analysis of variance, trend analysis, and Tukey's Studentized Range (HSD) Test ( $r$ $\leq 5 \%$ ). Photoperiod, temperature, and irradiance experiments were terminated at 72,54 (60 for the repeated experiment), and 62 days, respectively, when all plants reached visible flower buds.

\section{Results and Discussion}

Photoperiod. Photoperiod had a significant effect on flowering and plant height, but not on shoot dry weight (Table 1). All plants in the $16-\mathrm{h} \cdot \mathrm{day}^{-1}$ photoperiod produced flower buds with an average time to reach visible bud of 27 days from the beginning of photoperiod treatment (data not shown). Only 29\% of the plants in the 12-h photoperiod produced flower buds and none produced any in the 8-h photoperiod. These data suggest that Achillea millefolium 'Summer Pastels' is a qualitative long-day plant in which the effective photoperiod is between 12 and $16 \mathrm{~h}$. The greater height in the 16-h photoperiod reflects the presence of the flowering stem rather than a response of internodal tissue. Since temperature and cumulative light were similar for all three treatments, we expected plant dry weights to be similar.

Temperature. The data from the two experiments showed the same statistical trends, so they were combined. Flowering occurred at all temperatures; however, the effect of temperature on formation of flower buds and

Table 1. Influence of photoperiod on flowering and growth of Achillea millefolium 'Summer Pastels' (temperature: $20 \pm 2 \mathrm{C}$; irradiance: $5.8 \pm 0.4 \mathrm{~mol} \cdot \mathrm{m}^{-2} \cdot \mathrm{d}^{-1}$ ). Data were taken 72 days after the beginning

\begin{tabular}{llcr}
\hline $\begin{array}{l}\text { Photoperiod } \\
(\mathrm{h})\end{array}$ & $\begin{array}{c}\text { Flowering status } \\
(\% \text { of plants })\end{array}$ & $\begin{array}{c}\mathrm{Ht} \\
(\mathrm{cm})\end{array}$ & $\begin{array}{c}\text { Dry wt } \\
(\mathrm{g})\end{array}$ \\
\hline 8 & Vegetative (100) & $4.5 \pm 0.51$ & $12.2 \pm 0.44$ \\
12 & Vegetative (71) & $9.0 \pm 7.80$ & $11.8 \pm 0.84$ \\
16 & With flower buds (29) & $47.5 \pm 3.70$ & $13.2 \pm 1.06$ \\
Significance $^{\mathrm{z}}$ & Anthesis (100) & $\mathrm{L}^{*}, \mathrm{Q}^{*}$ & $\mathrm{NS}$ \\
\hline
\end{tabular}


anthesis followed a quadratic trend (Table 2). Visible flower buds formed much more rapidly at 18 and 26 than at 10C. Plant height showed a significant quadratic response to temperature. Plants grown at $18 \mathrm{C}$ were significantly taller than the others (Table 2). This result suggests that the net photosynthesis of A. millefolium 'Summer Pastels' was higher at $18 \mathrm{C}$ than at 10 or $26 \mathrm{C}$. In general, height increased rapidly 1 week before the flower buds were visible and the rapid growth phase ended $\approx 2$ weeks after flower buds were visible (Fig. 1). Dry weight was highest at $18 \mathrm{C}$ and followed a quadratic response (Table 2). Thus, flowering and growth of A. millefolium 'Summer Pastels' were best at $18 \mathrm{C}$; $26 \mathrm{C}$ resulted in shorter, more compact plants.

Irradiance. Time to visible flower bud responded linearly to irradiance; low (100 $\mu \mathrm{mol} \cdot \mathrm{m}^{-2} \cdot \mathrm{s}^{-1}$ ) irradiance delayed flowering. Time to anthesis was significantly shortened with increasing irradiance (Table 3 ), but it had no significant effect on the interval from visible bud to anthesis (data not shown). The fact that plants flowered at all under such low irradiance suggests that yarrow tolerates shading, supporting the work of Bourdot et al. (1984). Plant height, however, responded quadratically to irradiance, with plants grown under the medium irradiance the tallest (Table 3 ). Dry weight increased linearly with irradiance (Table 3 ).

These results provide useful guidelines for forcing A. millefolium 'Summer Pastels'. Photoperiod was a key factor in flower formation. 'Summer Pastels' is a qualitative long-day plant with a critical photoperiod between 12 and $16 \mathrm{~h}$, and temperature and irradiance also influence time of flowering. Temperatures $>10 \mathrm{C}$ and moderate light levels or higher $(\geq 200$ $\left.\mu \mathrm{mol} \cdot \mathrm{m}^{-2} \cdot \mathrm{s}^{-1}\right)$ in combination with long days may permit producing this cultivar as a greenhouse crop.

\section{Literature Cited}

Armitage, A.M. 1987a. Achillea. Amer. Nurseryman 166(7):94-99.

Armitage, A.M. 1987b. The influence of spacing on field-grown perennial crops. HortScience 22:904-907.

Armitage, A.M. 1992. Field studies of Achillea as a

Table 2. Effect of temperature on flowering and growth of Achillea millefolium 'Summer Pastels'. Data are the mean of the two experiments (photoperiod: $16 \mathrm{~h} \cdot \mathrm{day}^{-1}$; irradiance: $100 \mu \mathrm{mol} \cdot \mathrm{m}^{-2} \cdot \mathrm{s}^{-1}$ ). Data were taken 54 and 60 days after the beginning of treatments.

\begin{tabular}{lccc}
\hline \hline $\begin{array}{l}\text { Temp } \\
\left({ }^{\circ} \mathrm{C}\right)\end{array}$ & $\begin{array}{c}\text { Days to } \\
\text { visible bud }\end{array}$ & $\begin{array}{c}\mathrm{Ht} \\
(\mathrm{cm})\end{array}$ & $\begin{array}{c}\text { Dry wt } \\
(\mathrm{g})\end{array}$ \\
\hline 10 & $50 \pm 4.9$ & $26.2 \pm 2.36$ & $3.7 \pm 0.23$ \\
18 & $31 \pm 4.2$ & $51.4 \pm 4.30$ & $8.0 \pm 1.12$ \\
26 & $33 \pm 5.0$ & $34.0 \pm 1.40$ & $6.5 \pm 0.81$ \\
Significance $^{2}$ & $\mathrm{Q}^{*}$ & $\mathrm{Q}^{*}$ & $\mathrm{Q}^{*}$ \\
\hline
\end{tabular}

${ }^{\mathrm{z}} \mathrm{Q}=$ quadratic trend.

*Significant at $P \leq 0.05$.

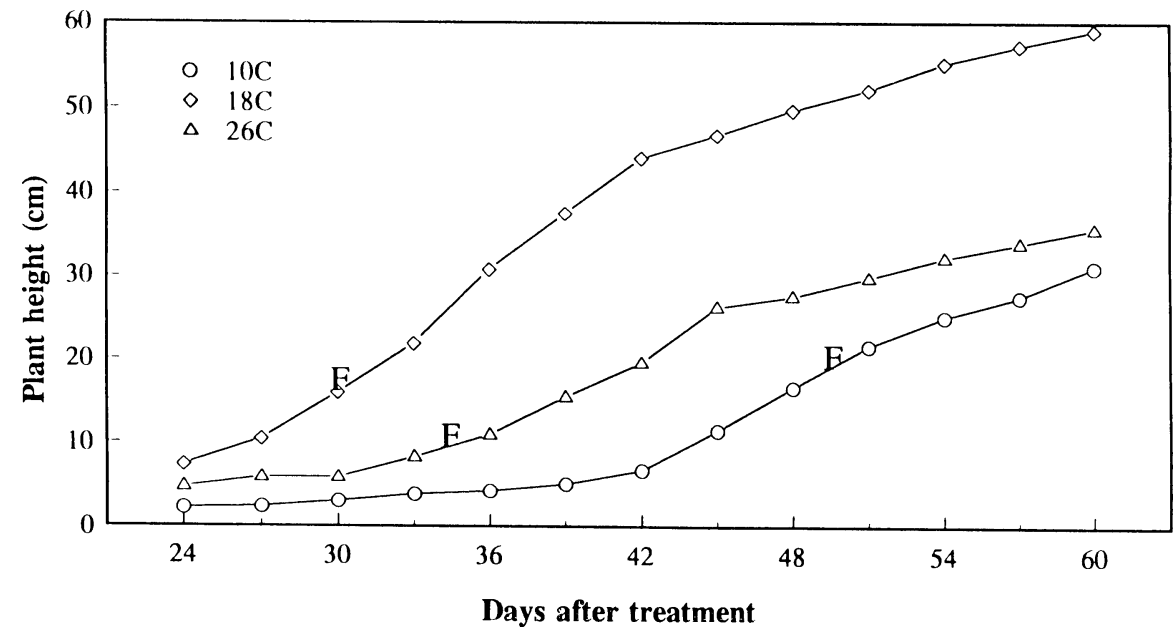

Fig. 1. Effect of temperature on height of Achillea millefolium 'Summer Pastels' over time (F: time to visible flowering buds).

Table 3. Influence of irradiance on flowering and growth of Achillea millefolium 'Summer Pastels' (photoperiod: $16 \mathrm{~h} \cdot \mathrm{day}^{-1}$; temperature: 20C). Data taken 62 days after the beginning of treatments.

\begin{tabular}{lcccc}
\hline $\begin{array}{l}\text { Irradiance } \\
\left(\mu \mathrm{mol} \cdot \mathrm{m}^{-2} \cdot \mathrm{s}^{-1}\right)\end{array}$ & $\begin{array}{c}\text { Days to } \\
\text { visible bud }\end{array}$ & $\begin{array}{c}\text { Days to } \\
\text { anthesis }\end{array}$ & $\begin{array}{c}\mathrm{Ht} \\
(\mathrm{cm})\end{array}$ & $\begin{array}{c}\text { Dry wt } \\
(\mathrm{g})\end{array}$ \\
\hline $100($ low $)$ & $34 \pm 5.0$ & $57 \pm 8.1$ & $37.5 \pm 6.8$ & $10.8 \pm 1.8$ \\
200 (medium) & $26 \pm 4.4$ & $45 \pm 7.4$ & $50.9 \pm 4.6$ & $17.5 \pm 1.3$ \\
300 (high) & $21 \pm 3.2$ & $37 \pm 5.8$ & $39.6 \pm 5.3$ & $21.6 \pm 2.4$ \\
Significance & $\mathrm{L}^{*}$ & $\mathrm{~L}^{*}$ & $\mathrm{Q}^{*}$ & $\mathrm{~L}^{*}$ \\
\hline
\end{tabular}

${ }^{\mathrm{x}} \mathrm{L}=$ linear, $\mathrm{Q}=$ quadratic trend.

"Significant at $P \leq 0.05$.

cut flower: Longevity, spacing, and cultivar response. J. Amer. Soc. Hort. Sci. 117:65-67.

Armitage, A.M. 1993. Specialty cut flowers. Timber Press, Portland, Ore.

Bailey, L.H. 1976. Hortus third. MacMillan, New York.

Bourdot, G.W., D.J. Saville, and R.J. Field. 1984. The response of Achillea millefolium L. (yar- row) to shading. New Phytol. 97:653-663.

Engle, B.E., A.C. Cameron, and R.D. Heins. 1993. The effects of long days and short days on growth of several species of herbaceous perennials. HortScience 28:573. (Abstr.)

Iversen, R.R. 1989. Greenhouse forcing of herbaceous garden perennials. PhD Diss., Cornell Univ., Ithaca, N.Y. 